\title{
O012: Can DAV132, a medical device targeting an adsorbent to the late ileum, decrease significantly the impact of antibiotics on the fecal microbiota?
}

\author{
N Grall ${ }^{1}$, E Chachaty ${ }^{2}$, S Sayah-Jeanne ${ }^{3}$, J de Gunzburg ${ }^{3}$, A Andremont ${ }^{*}$ \\ From 2nd International Conference on Prevention and Infection Control (ICPIC 2013) \\ Geneva, Switzerland. 25-28 June 2013
}

\begin{abstract}
Introduction
During antibiotic treatments a fraction of the dose impacts the intestinal microbiota, promoting spread of resistant bacteria (RB). Antibiotics can be inactivated by adsorption. DAV132 is an oral medical device to deliver an adsorbent in the late ileum. We investigated if DAV132 could reduce fecal antibiotics and RB excreted.
\end{abstract}

\section{Methods}

Three models were used. First, to explore the relationship between antibiotic exposure and excretion of RB, piglets just received 15 or $1.5 \mathrm{mg} / \mathrm{Kg} / \mathrm{d}$ of oral ciprofloxacin or placebo X 5 days. We then compared between groups fecal ciprofloxacin concentrations and the amount of RB excreted. Second, to explore colonic adsorption of antibiotics by DAV132 in the colon, dogs received $10.7 \mathrm{mg} / \mathrm{kg} / \mathrm{d}$ of IV levofloxacin X 5 days together with 0.3 or $0.6 \mathrm{~g} / \mathrm{kg} / \mathrm{d}$ or placebo of oral DAV132. We then compared between groups fecal and blood levofloxacin concentrations. Last, to explore if DAV132 could restore antibiotic-associated disruption of colonization resistance (CR), mice received $300 \mathrm{mg} / \mathrm{kg} / \mathrm{d}$ of sc cefotaxime or placebo X 3 days, together with $50 \mathrm{mg} / \mathrm{d}$ or placebo of oral DAV131 (DAV132 adapted to the mice), followed by gastric challenge with $10^{6} \mathrm{CFU}$ of a K. pneumoniae resistant to third generation cephalosporin (C3GR-Kp). We then compared between groups fecal cefotaxime and C3GR-Kp concentrations.

\section{Results}

In piglets, counts of $\mathrm{RB}$ excreted were 9.2, 8.8 and 6.2 $\log 10 \mathrm{CFU}$ in animals receiving respectively the 15 , the $1.5 \mathrm{mg} / \mathrm{kg} / \mathrm{d}$ and the placebo regimen respectively
( $\mathrm{p}<0.001)$. In dogs, reduction of fecal levofloxacin reached 71 and $82 \%$ when 0.3 or $0.6 \mathrm{~g} / \mathrm{kg} / \mathrm{d}$ of DAV132 was given. Blood PK of levofloxacin was not modified significantly. In mice, all antibiotic disappeared from the pellets when DAV131 was given to the animals together with cefotaxime and a significant part of RC by C3GR-Kp was restored.

\section{Conclusion}

Oral DAV132 might reduce exposure of the intestinal flora by antibiotics which could be associated with decrease in fecal excretion of RB without affecting blood PK. There appeared to be a relationship between the dose of DAV132 administered and the effect observed. The possible clinical use of DAV132 is under investigation.

\section{Disclosure of interest}

N. Grall: None declared, E. Chachaty Consultant for DA VOLTERRA, S. Sayah-Jeanne Employee of DA VOLTERRA, J. de Gunzburg Shareholder of DA VOLTERRA, A. Andremont Consultant for DA VOLTERRA.

\section{Author details \\ ${ }^{1}$ Lab. de Bacteriologie Hop. Bichat Claude-Bernard, Paris, France. ${ }^{2}$ Institut Gustave-Roussy, Villejuif, France. ${ }^{3}$ Da Volterra, Paris, France.}

Published: 20 June 2013

doi:10.1186/2047-2994-2-S1-012

Cite this article as: Grall et al:: 0012: Can DAV132, a medical device targeting an adsorbent to the late ileum, decrease significantly the impact of antibiotics on the fecal microbiota? Antimicrobial Resistance and Infection Control 2013 2(Suppl 1):012.

${ }^{1}$ Lab. de Bacteriologie Hop. Bichat Claude-Bernard, Paris, France

Full list of author information is available at the end of the article

(c) 2013 Grall et al; licensee BioMed Central Ltd. This is an Open Access article distributed under the terms of the Creative Commons Attribution License (http://creativecommons.org/licenses/by/2.0), which permits unrestricted use, distribution, and reproduction in any medium, provided the original work is properly cited. 